\title{
Mayaro and Chikungunya; two alphaviruses with clinical and epidemiological similarities
}

\section{Mayaro y Chikungunya; dos alfavirus con similitudes clínicas y epidemiológicas}

In 1780, Philadelphia suffered an unusual outbreak of hemorrhagic fever, which years later was identified as dengue (1). One hundred years later, in Memphis, 1500 people died from yellow fever, which caused residents to abandoned the city (2). Even though these stories may seem anecdotes, they show how dramatic hemorrhagic arbovirus outbreaks can be.

The tropic host arboviruses such as Chikungunya (CHIKV), Dengue, and Zika (ZIKV); but there are others, such as Mayaro, Oropuche, and Bussuquara, among others, which have still not been studied in depth by the public health systems of our countries.

Mayaro fever is a febrile illness caused by the Mayaro (MAYV) virus, a RNA alphavirus of the Togaviridae family. There are 29 species of alphaviruses, including relevant arboviruses that cause human and animal health problems, like the Venezuelan encephalitis virus, East encephalitis virus, West encephalitis virus, and CHIKV, new to the Latin American and the Caribbean epidemiology since 2014.

MAYV was first isolated in Trinidad in 1954, from blood samples obtained from farmers who lived in an area called Mayaro, after which it was named (1). MAYV has been detected in Mexico, Costa Rica, Panama, Peru, Colombia, Surinam, Guyana, Venezuela, Ecuador, Bolivia, and Brazil. Two genotypes of MAYV have been described in the Americas: genotype $D$, found in Trinidad, Peru, Venezuela, Colombia, Argentina, Guyana, Surinam, Bolivia, and Brazil, and genotype L, found in the amazon region of Brazil (4). MAYV outbreaks have occurred in rural and urban regions in Brazil, MAYV and the Oropuche viruses are, aside from Dengue, common causes of febrile syndromes in Brazil. Thus, since 2011 it was included as a notifiable disease $(2,3)$.

MAYV is transmitted onto humans by infected mosquitoes of the Haemagogus genus, especially Haemagogus janthinomys. Other vectors include
En Filadelfia, en 1.780 hubo una extraña epidemia de fiebre hemorrágica que los investigadores años después demostraron que fue dengue (1). Un siglo más tarde, en Memphis, murieron 1500 personas de fiebre amarilla, lo que causó el abandono del pueblo (2). Aunque estos relatos parecen anecdóticos, ellos demuestran lo dramático que pueden llegar a ser las epidemias de los arbovirus hemorrágicos.

En el trópico están presentes algunos arbovirus como el Chikungunya (CHIKV), Dengue y Zika (ZIKV); pero existen otros como Mayaro, Oropuche y Bussuquara entre otros, que todavía los sistemas de salud pública de nuestros países no los han estudiado profundamente.

La fiebre Mayaro es una enfermedad febril causada por el virus Mayaro (MAYV), un ARN alfavirus de la familia Togaviridae. Los alfavirus tienen 29 especies e incluyen importantes arbovirus que causan problemas de salud humana y animal, como los virus de las encefalitis venezolana, del Este, Oeste y el CHIKV; nuevo en la epidemiología de Latino América y del Caribe desde 2014.

El MAYV fue aislado por primera vez en Trinidad en 1954 de muestras de sangre de campesinos habitantes de una área llamada Mayaro de donde tomó su nombre (1). El MAYV se ha detectado en México, Costa Rica, Panamá, Perú, Colombia, Surinam, Guyana, Venezuela, Ecuador, Bolivia y Brasil. Dos genotipos de MAYV se han descrito en las Américas: el genotipo D, observado en Trinidad, Perú, Venezuela, Colombia, Argentina, Guyana, Surinam, Bolivia y Brasil y el genotipo L, observado en la región amazónica de Brasil (4). Los brotes de MAYV han ocurrido en áreas rurales y urbanas de la región amazónica de Brasil, el MAYV y el virus de Oropuche después de dengue son causas frecuentes de síndromes febriles en Brasil. Por esta razón, desde 2011 fue incluida como enfermedad de notificación $(2,3)$.

El MAYV se transmite a los humanos por picaduras de mosquitos infectados pertenecientes al género Haemagogus, principalmente Haemagogus janthinomys. Otros vectores son mosquitos del 
the Culex and Psophors sabethes genera. Primates and birds act as primary amplifying hosts. Evidence of MAYV infection has been found in primates (Callithix argentata, Callithix sp, Alouatta seniculus, Pithecia pithecia, Saimiri sciureus), marsupials (Philander oposum, Caluromyis philander), rodents (Agutíes sp., Oryzomys sp., Proechimys sp., Nectomys) and birds.

MAYV produces an acute febrile illness, with signs and symptoms similar to CHIKV, yellow fever, and dengue. Incubation period is 3-5 days; signs include fever, chills, myalgia, arthralgia, and maculopapular exanthema. Rash appears by the fifth day of illness, and lasts three days. Most of the symptoms disappear in 3-10 days; unlike CHIKV, it does not show recurrence. However, arthralgia can persist between two and twelve months. Unusual symptoms such as hemorrhage, thrombocytopenia, jaundice, and encephalitis have been described in patients with MAYV in Mexico, and one of them died of encephalitis $(2,3)$. There are no vaccines or specific treatment against MAYV. Those infected must remain resting, and they are treated for their symptoms with acetaminophen and nonsteroid anti-inflammatories (5).

A study carried out between 2010 and 2013 in the Peruvian amazon showed that arthralgia produced by MAYV were present in over $50 \%$ of the patients. The virus mainly affected joints in hands, wrists, elbows, feet, and knees, and in rare occasions, hips (6). Like CHIKV, articular pain in MAYV patients causes temporary disability, but patients with CHIKV have shown arthralgia for up to 3 years after the acute disease. Joints that are mainly affected include fingers, wrists, knees, and ankles (9). The economic and social impact of Mayaro fever has been less than those caused by Chikungunya and Dengue.

The jungle distribution of vectors and hosts of Mayaro fever has limited human outbreaks to rural areas close to tropical forests. However, MAYV can be introduced to other regions in the Americas by sick travelers or migratory birds, and it may adapt to compatible urban vectors such as Aedes aegypti and albopictus (10).

Many of the vectors and hosts for MAYV are found in Colombia, but it is unclear if the virus is silently circulating among other arbovirosis with similar symptoms like dengue and Chikungunya. There are no publications in Colombia about the MAYV isolation by culture. However, in 1964, seroprevalence of MAYV or an antigenically similar virus was studied in the Gulf of Uraba, the Eastern plains, and the valleys of the high género Culex y Psophors sabethes. Los primates y las aves actúan como hospederos primarios amplificadores. Se ha encontrado evidencia de infección con MAYV en primates (Callithix argentata, Callithix sp, Alouatta seniculus, Pithecia pithecia, Saimiri sciureus), marsupiales (Philander oposum, Caluromyis philander), roedores (Agutíes sp., Oryzomys sp., Proechimys sp., Nectomys) y aves.

EI MAYV produce una enfermedad febril aguda con signos y síntomas similares al CHIKV, fiebre amarilla y dengue. El periodo de incubación es de 3-5 días; se presenta fiebre, escalofríos, mialgias, artralgias y exantema maculopapular. La erupción aparece alrededor del quinto día de la enfermedad y persiste por tres días. La mayoría de los síntomas desaparecen entre 3-10 días; a diferencia del CHIKV, no presenta recurrencias. Sin embargo, las artralgias pueden durar entre dos y doce meses. Síntomas inusuales como hemorragias, trombocitopenia, ictericia y encefalitis se han descrito en pacientes con MAYV en México, uno de ellos falleció a causa de la encefalitis $(2,3)$. No hay vacunas ni drogas específicas contra MAYV. Las personas afectadas deben permanecer en reposo y son tratadas sintomáticamente con acetaminofén y antiinflamatorios no esteroideos (5).

En un estudio realizado entre 2010 y 2013 en la Amazonía peruana, se observó que las artralgias producidas por MAYV estuvieron presentes en más del $50 \%$ de los pacientes. El virus afectó principalmente las articulaciones de las manos, muñecas, codos, pies y rodillas y en raras ocasiones la cadera (6). Los dolores articulares de pacientes con MAYV, al igual que en CHIKV producen incapacidad temporal, pero pacientes con CHIKV han presentado artralgias hasta 3 años después de haber padecido la enfermedad aguda. Las principales articulaciones afectadas son la de los dedos, muñecas, rodillas y tobillos (9). El impacto económico y social de la fiebre Mayaro ha sido menor que el del Chikungunya y del Dengue.

La distribución selvática de los vectores y hospederos de la fiebre Mayaro ha restringido la mayoría de los brotes en humanos a las áreas rurales cercanas a bosques tropicales. No obstante, el MAYV puede ser introducido a otras regiones de las Américas por viajeros enfermos o aves migratorias y puede adaptarse a vectores urbanos compatibles como el Aedes aegypti y albopictus (10).

Muchos de los vectores y hospederos de MAYV se encuentran en Colombia, pero no se conoce con certeza si el virus está circulando de forma silenciosa entre otras arbovirosis con sintomatología similar, como dengue y Chikungunya. En Colombia no se conocen publicaciones científicas que notifiquen la presencia de MAYV por aislamiento viral. No obstante, en 1964 la seroprevalencia de MAYV o un virus antigénicamente similar, fue estudiada en el 
and middle Magdalena. In humans and primates Alouatta, Cebus y Saimiri sera were positive by neutralization and hemagglutination tests (11).

As described in previous editorials, emerging viruses in Latin America such as Zika, Chikungunya, Oropuche, and Heartland require a more serious study, because not all tropical fevers are dengue. golfo de Urabá, Llanos orientales y valles del alto y medio Magdalena. Los resultados por neutralización y hemaglutinación fueron positivos para sueros humanos y de primates del género Alouatta, Cebus y Saimiri (11).

Como se describió en editoriales anteriores, los virus emergentes en Latinoamérica como Zika, Chikungunya, Oropuche y Heartland merecen un estudio más serio porque no todas las fiebres tropicales son dengue.

Salim Mattar V. Ph.D. Marco González T. M.Sc.

\section{REFERENCES}

1. Anderson CR, Downs WG, Wattley GH, Ahin NW, Reese AA. Mayaro virus: a new human disease agent. II. Isolation from blood of patients in Trinidad, BW I. Am J Trop Med Hyg 1957; 6(6):1012-6.

2. Napoleão-Pego $P$, Gomes $L$, Provance-Jr D, De-Simone S. Mayaro Virus Disease. J Hum Virol Retrovirol 2014; 1(3):00018.

3. Slegers C, Keuter M, Günther S, SchmidtChanasit J, van der Ven A, de Mast Q. Persisting arthralgia due to Mayaro virus infection in a traveler from Brazil: Is there a risk for attendants to the 2014 FIFA World Cup?. J Clin Virol 2014; 60(3):317-319.

4. Powers AM, Aguilar PV, Chandler LJ, Brault AC, Meakins TA, Watts $D$, et al. Genetic relationships among Mayaro and Una viruses suggest distinct patterns of transmission. Am J Trop Med Hyg 2006; 75(3):461-469.

5. Figueiredo MLGd, Figueiredo LTM. Emerging alphaviruses in the Americas: Chikungunya and Mayaro. Rev Soc Bras Med Trop 2014; 47(6):677-83.

6. Halsey ES, Siles C, Guevara C, Vilcarromero S, Jhonston EJ, Ramal C, et al. Mayaro virus infection, Amazon basin region, Peru, 20102013. Emerg Infect Dis 2013; 19(11): 1839.
7. Forshey B, Guevara C, Laguna-Torres V, Cespedes M, Vargas J, Gianella A, et al. Arboviral etiologies of acute febrile illnesses in Western South America, 2000-2007. PLoS Negl Trop Dis 2010; 4(8):e787.

8. Muñoz M, Navarro JC. Virus Mayaro: un arbovirus reemergente en Venezuela y Latinoamérica. Biomédica 2012; 32(2):288-302.

9. Schilte C, Staikowsky F, Couderc T, Madec Y, Carpentier F, Kassab S, et al. Chikungunya virus-associated long-term arthralgia: a 36-month prospective longitudinal study. PLoS Negl Trop Dis 2013;7(3):e2137.

10. Long KC, Ziegler SA, Thangamani S, Hausser NL, Kochel TJ, Higgs $S$, et al. Experimental transmission of Mayaro virus by Aedes aegypti. Am J Trop Med Hyg 2011; 85(4):750-7.

11. Groot H. Estudios sobre virus transmitidos por artrópodos en Colombia. Rev Acad Colomb Cien Exac Fis Nat 1964; 12:3-23. 